\title{
Mitigating the catastrophic impacts of torrential rivers in semi-arid environments: a case of the Gash River in eastern Sudan
}

\author{
Samir Mohammad Ali Alredaisy* \\ Department of Geography, Faculty of Education, University of Khartoum, Omdurman 406, Sudan
}

\begin{abstract}
The climatic, geomorphic, hydrologic and aquifer characteristics of the torrential Gash River across mountainous areas, in far eastern Sudan, were analyzed in order to mitigate its recurring catastrophic impacts. Hydrologic and climatic data and interpretation of Gash River satellite images were from relevant research works carried out in Gash Basin from 1985 to 2008. The results indicated that the total catchment area of Gash River is about $21,000 \mathrm{~km}^{2}$, and the basin area is $31,000 \mathrm{~km}^{2}$. The total length of Gash River is $450 \mathrm{~km}$ and the average slope is $200 \mathrm{~cm} / \mathrm{km}$. The width of the catchment varies from $30 \mathrm{~m}$ to $90 \mathrm{~m}$ and that of the basin is from $100 \mathrm{~m}$ to 800 $\mathrm{m}$, and the course of the river is varied. During the period of 1980-2008, the mean annual rainfall was $250 \mathrm{~mm}$ and the mean annual discharge was $6.8 \times 10^{8} \mathrm{~m}^{3}$, and the flooding is approximately one time per 5 years. Torrential floods measured at Kassala town since 1907 showed that an absolute maximum discharge was $876 \mathrm{~m}^{3} / \mathrm{s}$ and a mean maximum discharge was $365 \mathrm{~m}^{3} / \mathrm{s}$. These characteristics differ widely between catchment and basin areas. The author proposes that, by analyzing the climatic, geomorphic, hydrologic and aquifer characteristics of the Gash River and considering the role of community, a concise database could be provided to formulate the aquifer, geomorphic, hydrologic and climatic (AQUIGEOHYCLIM) regional approach to mitigate Gash River recurring catastrophic impacts.
\end{abstract}

Keywords: AQUIGEOHYCLIM; Gash River; basin; climate; geomorphology; hydrology; mitigation; water management

Understanding the hydrologic behavior of rivers is important to avoid hazards, which might be initiated by outstanding floods. In semi-arid regions the characteristics of the river flow can be classified as perennial, seasonal and ephemeral (Lerner et al., 1990). Important hydrological processes in semi-arid regions which determine hydrologic behavior of rivers include precipitation, evapotranspiration, overland flow, river flow and discharge. In such regions, rainfall events are in general of short duration and high intensity and often characterized by large spatial heterogeneity and probably torrential downpour (Pilgrim et al., 1988; Wheater et al., 1991; Martinez-Mena et al., 2001; Wheater, 2008). The proclamation of torrential rain simply means that the amount of rain is abundant, and the rain has a fast on-set, or lasts for a long period of time (Oblack, 2010). These characteristics are even more pronounced in regions with topographic complexity such as mountain ranges. As a result of the spatial variability of landscape characteristics, such as geology, topography, soil, land use and vegetation, evapo-transpiration, will likewise exhibit spatial variation (Güntner and Bronstert, 2004). Evapotranspiration is controlled by meteorological conditions, ground surface, vegetation cover and soil characteristics.

For hilly and mountainous catchments, such as that of Gash River, with relatively sparse vegetation cover and high rainfall intensity, overland flow generation frequently occurs (Wheater, 2008). According to the mechanisms responsible for overland flow generation,

Received 2011-01-06; accepted 2011-03-08

*Corresponding author: Samir Mohammad Ali Alredaisy (E-mail: samiralredaisy@yahoo.com) 
the Hortonian type of runoff or infiltration excess, overland flow refers to the situation, where heavy rainfall events exceed the infiltration capacity of the soil and thus lead to surface runoff, which is generally considered to be the dominant runoff generation in semi-arid regions (Pilgrim et al., 1988; Hughes, 1995). Runoff may re-infiltrate into the bottom of a valley or into a bed of alluvial sediments, or overland flow may be lost as infiltration into fractured bedrock channels. In all cases groundwater recharge is augmented (Hughes, 1995). Infiltrating discharge water contributes to groundwater recharge and associated groundwater flow in the river valley sediments. River discharge is a unique hydrological variable as it is the final outcome of a large number of vertical and horizontal flow processes within the whole catchment. In semi-arid regions evapotranspiration captures most water entering soil, and recharge occurs only at extreme rainfall events (Pilgrim et al., 1988). Furthermore, recharge usually only occurs in limited areas and generally it is non-existent or negligible over most semi-arid landscape at hill slopes.

Flood control refers to all methods used to reduce or prevent the detrimental effects of flood waters (Encarta, 2008). Flood mitigation involves managing flooding, rather than trying to prevent it altogether (Wikipedia, 2010). There are a variety of mitigation techniques available depending on the nature of the risk. The introduction of protective structures can affect the physical balance, so careful parameters have to be set for their design. Flood defense measures can include river's and coastal erosion protection schemes, river flow attenuation, strengthening of waterfront walls and banks, in-channel gates and weirs and flood-resilient building design. Sustainable flood protection should tackle the legacy of previous development in areas of high flood risk in a variety of ways, not always involving an engineered solution. 'Hard' defenses such as river walls may not always be a suitable long-term solution. Flooding is natural occurrence that is sometimes better contained and managed using 'soft' techniques, for example by enhancing existing flood meadows and salt marshes.

The flow in the Gash River can start with only trickle move, and reach up to $850 \mathrm{~m}^{3} / \mathrm{s}$ in very short time (Bashar et al., 2005). According to the available records, the years of 1921, 1926, 1927, 1929, 1931,
1932, 1939, 1941, 1950, 1952, 1973, 1974, 1975, 1983, 1988, 1992, 1998 and 2003 had catastrophic flood events. The flood in 1975 was considered to be one of the most damaging one. However, the flood in 2003 was more serious compared to that of 1975 . There is only $30 \mathrm{~km}$ distance for the Gash River to pass from the Sudanese-Eritrean border to Kassala town, which took only about 4 hours for the flood wave to reach Kassala town without enough time for warning and preparing. At that time, some calls were raised to transfer Kassala town, the capital of the region, to another place to avoid Gash River floods.

The main objective of this paper is to mitigate hazards caused by high flooding of the Gash River. And the objective can be achieved through the "AQUIGEOHYCLIM" (aquifer, geomorphic, hydrologic and climatic) regional approach.

\section{Study area and methods}

The Gash River basin is located at $36^{\circ} 20^{\prime}-36^{\circ} 35^{\prime} \mathrm{E}$ and $15^{\circ} 10^{\prime}-15^{\circ} 25^{\prime} \mathrm{N}$ (Fig. 1), and the river is a seasonally torrential and intermitted stream originating from the Eritrean highlands, flowing northwestwardly across the flat plain and ending at an inland fan delta which is the most important agricultural land in the area. When entering Sudan, the Gash River changes from a westerly direction to northerly one and attains the appearance of a wide shallow stream with a sandy bed and extensive flood plains on either side as far as Sabeel/Wad Sherefei (Fig. 1). Where the Gash River tends to widen and further goes northward its fan and then into an inland delta.

The main geological units consist of the Pre-Cambrian basement rocks and the alluvial deposits. The basement rocks comprise meta-sediments intruded by scattered outcrops of granitic composition. This basement complex represents the oldest rock units in Gash River area. The area is then subject to erosion, which made the area become a peneplain. The main outcrops of the basement are the granitic biotitic gneisses from the sedimentary origin of J. Kassala with an elevation of $1,346 \mathrm{~m}$ above sea level, and $\mathrm{J}$. Mukram which rose on the plain. In other places the basement complex was covered with Tertiary- Quaternary deposits.

The satellite image of Kassala area provided by the Geological Research Authority of Sudan (ND 37 A- 
Sudan-Worksheet $1:$ 250,000, TM7/TM4/TM1(Fig. 2) was interpreted to obtain Gash River's geomorphic characteristics. Climatic data were from Sudan's Meteorological Department. Hydrologic data were from Ground Water and Valleys Directorate, Ministry of Irrigation. Relevant fieldworks were carried out by TNO-DGV Institute of Applied Geosciences, the Netherlands and National Water Corporation of Sudan during the period of 1978-1982. Recent results of the studies on channel-fill and sheet-flood facies sequences in the Gash River from Abdullatif (1989), on regional groundwater flow of the Gash River basin from Elkirail and Ibrahim (2008), and groundwater budget of the Gash River basin from Eltom et al. (2010) were used to obtain hydrologic and groundwater data of the Gash River.

The "AQUIGEOHYCLIM" regional approach, conceptually presented by Fig. 3, considered the Gash River as a geographic region and showed potential sources of the climatic, geomorphic, hydrologic and aquifer characteristics into better understanding of its hydrologic behavior in order to mitigate its catastrophic impacts. Climatic data on temperature, rainfall, and flooding or aridity determine the flow, regime and

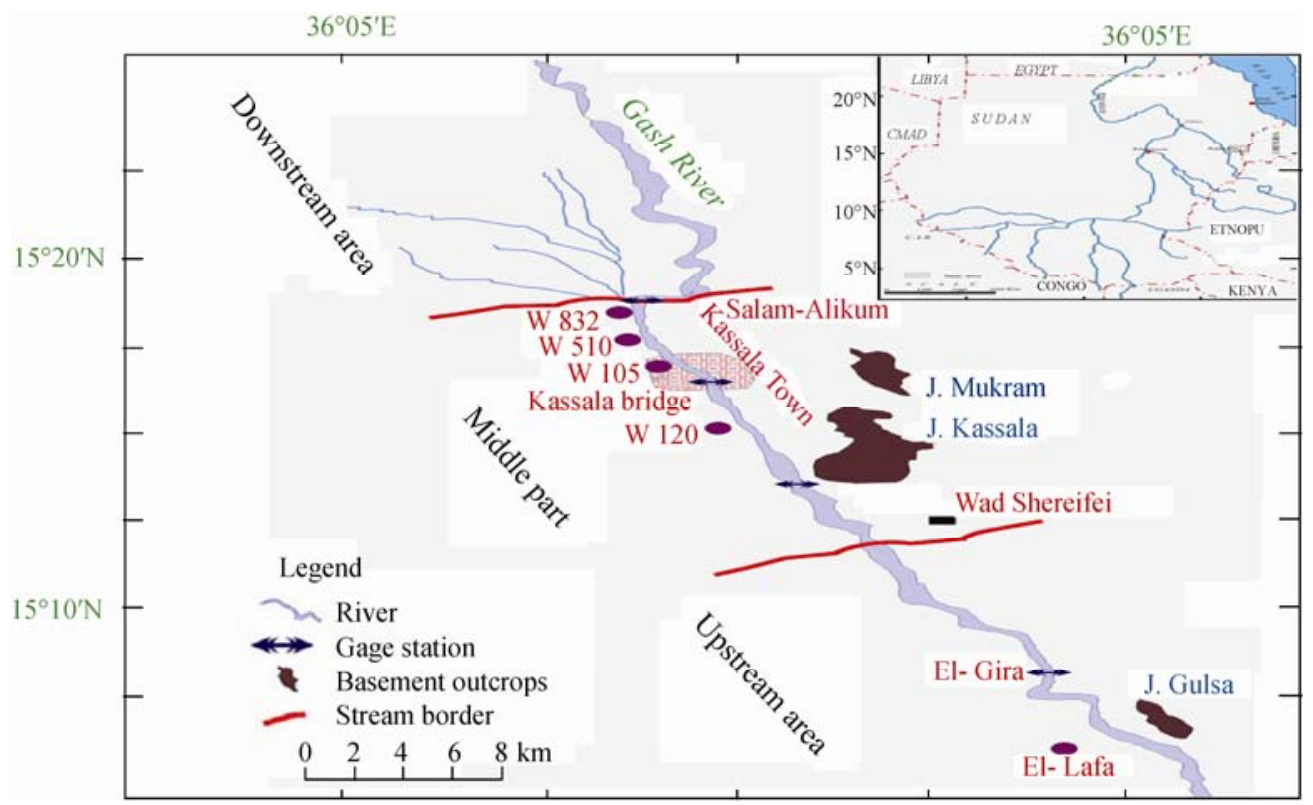

Fig. 1 Location of the Gash River Basin Source: Eltom et al. (2010)

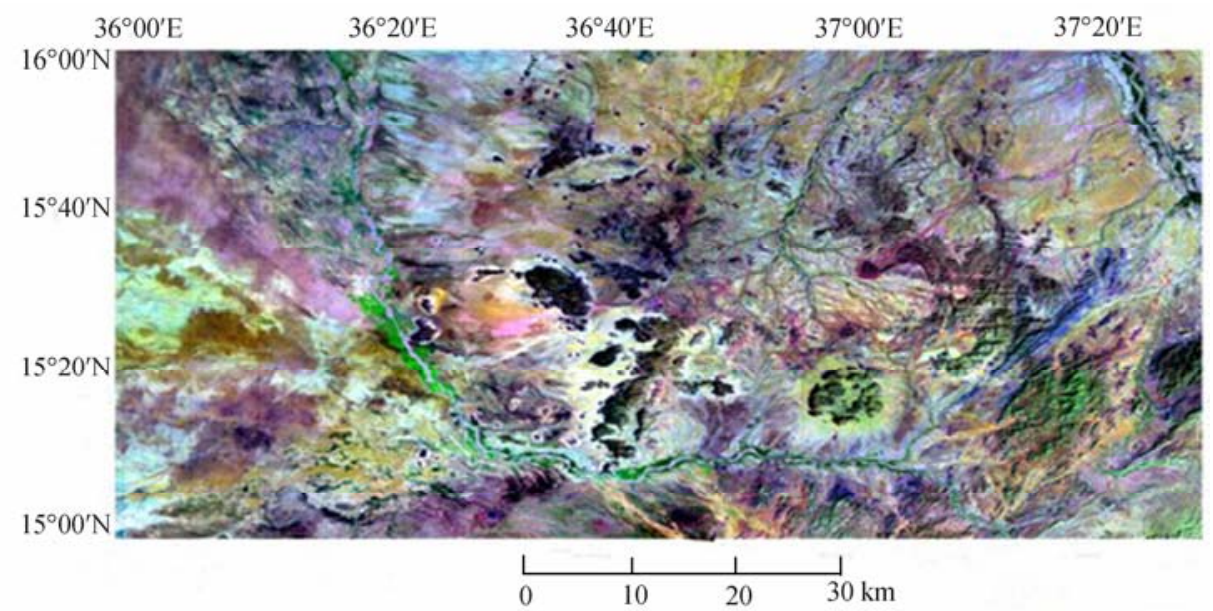

Fig. 2 Satellite image of the Gash River, showing its source, flow direction, the basin and inland delta Source: Geological Research Authority of Sudan, 2010 


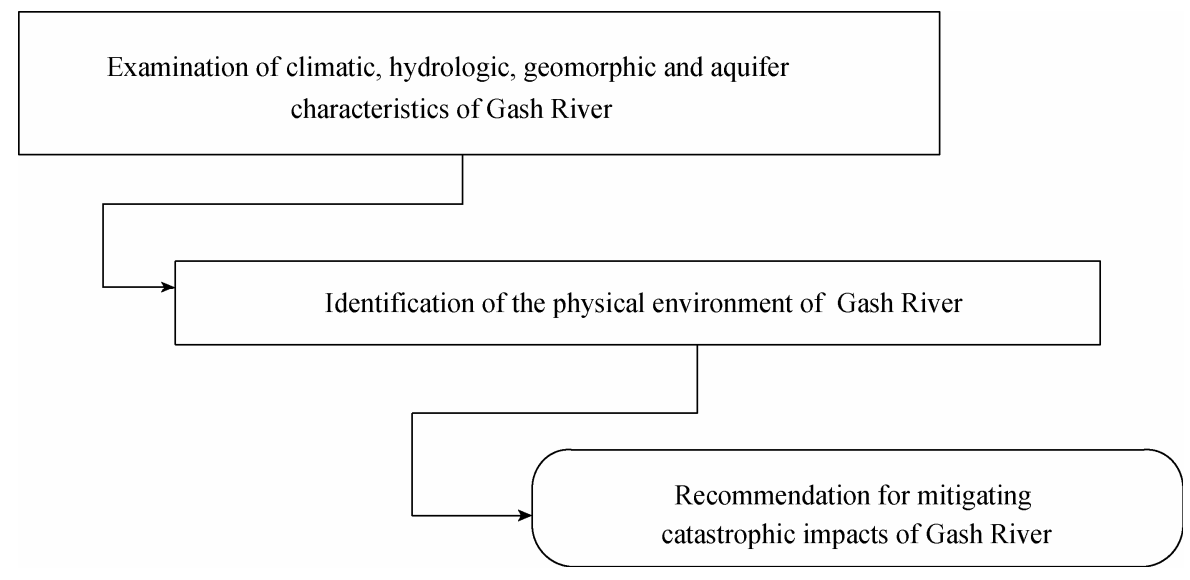

Fig. 3 Conceptual framework of "AQUIGEOHYCLIM" approach

seasonality of a river that affect its final outcome. Geomorphic data are essential to assess geomorphic processes and the resulting form of a river valley within which discharge is determined. Hydrologic data will help to understand about stream behavior and create awareness and ways to avoid its hazards. Aquifer data will help to understand about water movement, aquifer storage capacity and water withdrawal which can benefit for water storage during high floods. In addition, this approach considers community involvement as virtually important to mitigate the Gash River's catastrophic impacts.

\section{Results}

\subsection{Climatic, geomorphic, hydrologic and aquifer characteristics of the Gash River}

Main climatic, geomorphic, hydrologic and aquifer characteristics of the Gash River catchment and basin are summarized in Table 1. In Eritrea, the Gash River is perennial and becomes ephemeral before it enters Sudan. The elevation of the plateau is from 2,000 to $2,500 \mathrm{~m}$ above sea level, but as the river enters the Sudan Plains, its elevation drops to about $600 \mathrm{~m}$ and further drops to $350 \mathrm{~m}$ at Kassala town in a distance of $35 \mathrm{~km}$. As a result, the speed of the current is reduced and the river begins to reduce its load of sediments. The river has the sandy bed with varying widths, well-defined banks and a varying bed slope. Before entering Sudan, the river passes a narrow rocky course while the flood plain is developed with dense palm trees. In Sudan, the Gash basin area is characterized by wide flood plains on both sides of the river bed.
Topography is flat to slightly rolling in the Gash-delta, with a gentle sloping towards the north-west. The elevation difference between southeast and northwest is small. There are many valleys supplying water to Gash River inside the Sudan (Fig. 2). The areas adjacent to the western part of flood plain are sloping westwards and more level terrain than the eastern part. The delta area is spacious and capable to receive more sudden floods. The Gash River basin has been classified as an evolving basin and the river is considered to be braided. The basin is filled by the Quaternary alluvial deposits, overlying the basement rocks with an unconformity. The alluvial deposits are composed mainly of unconsolidated layers of gravel, sand, silt and clay. The clay of the plain overlies the basement complex, Cretaceous sedimentary series and Tertiary lavas. The clay of the plain is usually developed on the river flood plain, east and west of alluvial deposits. It consists of laminated loose to compacted clay, silt and sandy silt. The alluvial deposits were formed by the action of Gash River during the flood seasons. The coarse materials (sand and gravel) are deposited on the upstream and the finer materials (clay) on the downstream. They are composed of intercalating beds of coarse unconsolidated to fine-grained gravel, sand, silt and clay. Detailed analysis of the Gash River fluvial sediments has revealed a number of facies and two distinct types of sequences: channel-fill and sheet-flood sequences. The Gash sediments show some similarities to and differences with those ephemeral and low-sinuosity braided streams. The predominance of sheet-flood deposits is consistent with the ephemeral flashy high flow regime 
Table 1 Summary of main geomorphic, climatic, hydrologic and aquifer characteristics of Gash River

\begin{tabular}{|c|c|}
\hline Geomorphic data & Climatic data \\
\hline $\begin{array}{l}\text { (1) Catchment area characteristics: } \\
\text { Area: } 21,000 \mathrm{~km}^{2} \\
\text { Width: } 30 \text { to } 90 \mathrm{~m} \\
\text { Length: } 250 \mathrm{~km} \\
\text { Perennial length: } 175 \mathrm{~km} \\
\text { Bank heights: } 1-2 \mathrm{~m} \\
\text { Average bed slope: } 2 \mathrm{~m} / \mathrm{km} \\
\text { (2) Basin characteristics: } \\
\text { Area: } 31,000 \mathrm{~km}^{2} \\
\text { Length: } 200 \mathrm{~km} \\
\text { Average slope: } 2 \mathrm{~m} / \mathrm{km} \\
\text { Width: } 100 \text { to } 800 \mathrm{~m} \\
\text { Flood plains width: } 1,000 \mathrm{~m} \\
\text { Elevation: } 1,500 \mathrm{~m} \text { (SE) }-450 \mathrm{~m}(\mathrm{NW}) \\
\text { Evolving basin: } \\
\text { Plains clay thickness: up to } 20 \mathrm{~m} \\
\text { Alluvial deposits thickness: upstream: } 30 \mathrm{~m} \text {; downstream: up to } 70 \mathrm{~m} \\
\text { Alluvial deposits thickness: } 17-34 \mathrm{~m} \\
\text { Plains clay thickness: } 18 \mathrm{~m} \\
\text { Aquifer characteristics: } \\
\text { Storage capacity: upper and middle parts, } 502 \times 10^{6} \mathrm{~m}^{3} \\
\text { Groundwater input: } 386.11 \times 10^{6} \mathrm{~m}^{3} / \mathrm{a} \\
\text { Groundwater output: } 365.98 \times 10^{6} \mathrm{~m}^{3} / \mathrm{a} \\
\text { Estimated difference between input and output water: } 20 \times 10^{6} \mathrm{~m}^{3} / \mathrm{a} \\
\text { Average saturated thickness: } 20-35 \mathrm{~m} \\
\text { Average annual groundwater replenishment: } 381 \times 10^{6} \mathrm{~m}^{3} \\
\text { Annual groundwater inflow: } 5.11 \times 10^{6} \text { and outflow: } 3.1 \times 10^{6} \mathrm{~m}^{3} / \mathrm{a} \\
\text { Water balance: } 20.13 \times 10^{6} \mathrm{~m} / \mathrm{a} \\
\text { Annual net recharge volumes: } 19.8 \times 10^{6} \text { and } 19.75 \times 10^{6} \mathrm{~m}^{3} \\
\text { Annual average recharge: } 19.78 \times 10^{6} \mathrm{~m}^{3} \text { (accounts for } 8.10^{3} \% \text { of the total) }\end{array}$ & 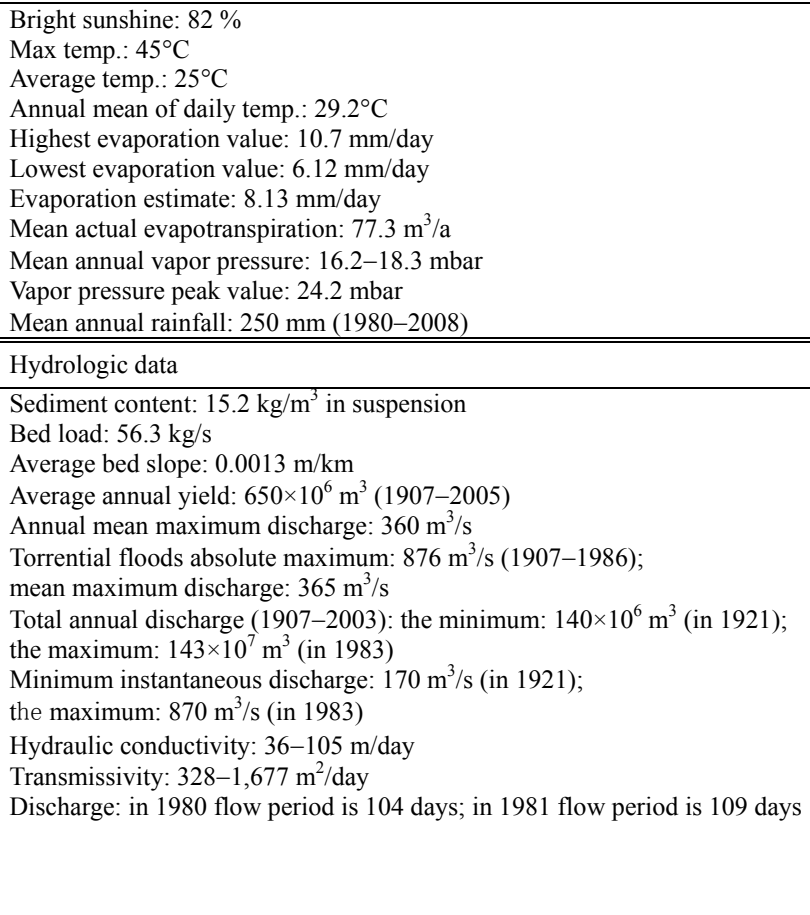 \\
\hline
\end{tabular}

in the Gash River. The non-conformity of the Gash River depositional style with the braided approach of fluvial deposition may be due to this semi-arid terminal flashy character which controls the depositional processes and patterns. It seems that the thick sediments of the Gash River were produced by braided channel aggradations and lateral migration and by both channelized and un-channelized sheet-flood deposition. Deposits of the two phases contribute to the sediments of the present-day Gash fluvial basin in the Kassala area.

The Gash basin area is characterized by semi-arid climate in which two main seasons can be distinguished. Firstly, the hot and dusty summer extends from April to October, with bright sunshine and maximum temperature, and secondly the winter season that extends from November to March. Relative humidity of the air has no significant changes during the day. The highest evaporation value occurs in June, while the lowest value in January and vapor pressure peak value in August. The rainy period starts in July and continues to the end of September. In dry climate of Kassala area, the moisture saturation is only reached during rainstorms. Generally, in the Gash delta rainfall rapidly decreases in a northern direction.

Copious amounts of rain when falling across the highlands regions of Ethiopia lead to high moisture, and form a very wet soil condition. There is no reliable rainfall data available in the catchment. Water levels of the Gash River threaten to overflow their banks potentially affecting areas near Kassala in Sudan. The Gash River in its mountainous catchment area in Eritrea, loses its water through evaporation and percolation, and is also utilized for irrigation and other purposes. In its lower reaches, the Gash River is an ephemeral river, usually flowing from early July to late September. Its flow is torrential and highly variable, with many types of sediment in suspension. Investigation of floods recorded since 1907 showed high torrential discharges. Because it is a braided river, the Gash River becomes wider and shallower where its flow takes many directions resulting in the changes of its course. The discharge measurements of the Gash River for the period 1907 to 2003 at Kassala gauging station showed high fluctuation and high variability of the flows. The annual loss amounts to $40 \%$ of the total discharge. The water loss is attributed to infiltration and evaporation. The discharge rating curves display relatively large residual variance which is largely caused by rapid spasmodically changes of the stream bed of the Gash River.

Monitoring of groundwater level measurements in- 
dicates that the water table rises during the rainy season in the upstream and midstream areas. The groundwater input exceeds groundwater output. The aquifer is unconfined and is laterally bounded by the impermeable Neogene clay. The groundwater occurs under confined and semi-confined conditions. With the continuous pumpage the confining effect of the upper bed may be reduced and the entire saturated portion will function as a water table aquifer. The recharge of aquifer is due to infiltration from the Gash River during flood seasons or direct precipitation. The general flow direction is towards the northwest. The Gash aquifer is composed of heterogeneous sequence of layers which are dominated by coarse sand, gravel, clayey sand and silt.

There are three sources of recharge of the alluvial aquifer in the Gash River basin; these are infiltration from surface water runoff of the Gash River and infiltration from direct rainfall and inflow of groundwater from the catchment area. The most important source of recharge is the infiltration from surface runoff between El Gera (upstream) and Salam-Alikum (downstream). The rate of recharge from direct rainfall depends on the amounts and duration of precipitation in the river basin. The groundwater loss in the upper and the middle parts of the study area is caused by the following elements of discharge, evaporation and discharge through pumping for irrigation and domestic uses and outflow to the Gash delta. Groundwater budget, the infiltration of surface water takes place at the beginning of the flood season when the running water removes the top layers of silt.

Climatic, hydrologic, geomorphic and the aquifer characteristics of Gash River have depicted a physically unified river system (Fig. 4). However, considering major differences between catchment and basin and within the basin itself will help to mitigate hazards of the Gash River. Rainfall amounts differ by twofold in minimum records and threefold in maximum records between catchment and basin (Fig. 4). The basin area exceeds the catchment area by 1,000 $\mathrm{km}^{2}$ which equals one third excess. There is a difference of $50 \mathrm{~km}$ in the length of the river in Sudan, which equals an excess by $11 \%$. Quick drop in the height of the plateau is by more than fourfold (2,500-2,000 $\mathrm{m}$ in catchment) and (600-350 $\mathrm{m}$ in the basin and delta). The river width in the catchment ranges between $30 \mathrm{~m}$ to $90 \mathrm{~m}$, while in the basin it ranges between $100 \mathrm{~m}$ and $800 \mathrm{~m}$. This gives threefold difference in the low record and eightfold difference in the high record between catchment and basin.

\section{2 “AQUIGEOHYCLIM” regional approach}

"AQUIGEOHYCLIM" regional approach considers the Gash River as environmentally and geographically integrated physical unit including catchment and basin areas, opposite to the efforts done in downstream to cure its torrential impacts. Because the study area is the part of the great African rift valley which is characterized by high mountains and faults, it might be difficult to utterly control the impacts of torrential rivers and to put a concise plan to use its water appropriately. But, if our approach is put into consideration, that is, the characteristics of the catchment and basin, and emphasizes on the inherited variations in geomorphic characteristics, rainfall inputs, discharges and aquifer within the Gash River, in addition to incorporating community efforts for mitigating flood of the Gash River, it is expected to be highly valuable.

Environmental information about torrential rivers in Sudan should include relevant data on the timing of the rainy season and all related climatic characteristics at the state and regional scales, to facilitate appropriate planning for control of flooding and expected incidence of catastrophes. Geomorphic, hydrologic and aquifer information should also be introduced. Geographical information should relate to location, position and latitude differences in order to detect hazardous areas. An access to the map showing catchments areas and internal discharge and floods in various regions of Sudan can help to forecast future river-behavior trends and their consequences for purposes of mitigation and management. The "AQUIGEOHYCLIM" model can also benefit from the available flood risk maps which show those areas prone to flooding of known return periods and GIS mapping survey data. In order to improve the quality of the surveys and to develop thematic maps to allow a more versatile use, the survey data should be produced in a geographical information system (GIS). GIS-system should be proposed to further enhance the interpretation of flood data and to provide possibilities for better spatial analysis. There is obvious need for using remote sensing fast to obtain reliable information on the extent of a flooding event. 
Catchment area characteristics

Torrential rains

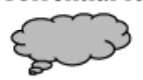

Rainfall fluctuates between $400-750$ mm annually

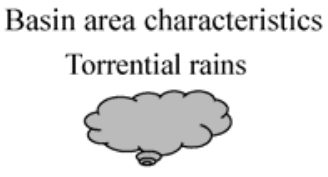

Hot dusty summer is from April to October; sunshine is $82 \%$, maximum temperature exceeds $45^{\circ} \mathrm{C}$. In winter season (November to March), average temperature is $25^{\circ} \mathrm{C}$. Annual mean of daily temperature is $29.2^{\circ} \mathrm{C}$; the highest evaporation in June is $10.7 \mathrm{~mm} /$ day, the lowest in January $6.12 \mathrm{~mm} /$ day; estimated evaporation is $8.13 \mathrm{~mm} /$ day; mean actual evapotranspiration is 77.3 $\mathrm{m}^{3} / \mathrm{a}$. The mean annual vapor pressure is $16.2-18.3 \mathrm{mbar}$. The rainy period is from July to the end of September with $250 \mathrm{~mm} / \mathrm{a}$; in the delta rainfall rapidly decreases in a northern direction

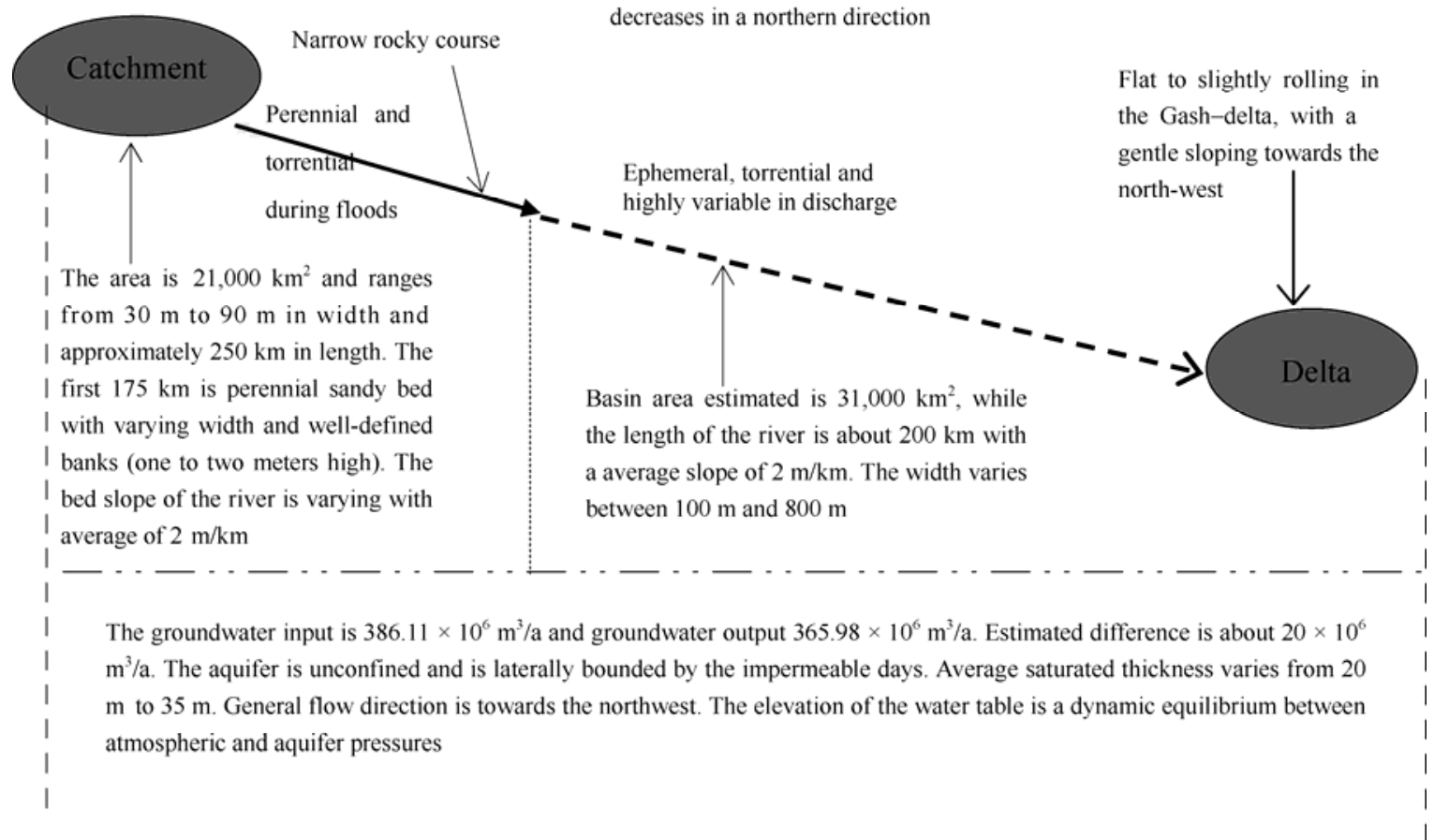

Fig. 4 Physical environment of Gash River, a unified operating open system

Some significant characteristics of flooding such as depth of water, flood duration, flow velocity, rate of rise, frequency, silt and debris have to be considered.

The formalization of methods for the assessment of flood burden provides a framework for standardized methods. Flood does not appear as a major disorder in Sudan's burden-of-disaster estimates, although national programs addressed the disasters such as drought disaster prevention, reliable hydrological information is needed on the burden and severity of the torrential floods in risk areas in order to achieve consensus on case definitions, diagnostic criteria, and the appropriate mix of preventive strategies. Including torrential rivers management as a tool to increase quality of use, improve outcomes, and control costs to reduce provider practice variation is a key aspect of the "AQUIGEOHYCLIM" regional approach. Strate- gies for administration of torrential rivers for preventing catastrophes should be deployed on a wide scale in "AQUIGEOHYCLIM", bearing in mind that the complete avoidance of catastrophes can be difficult. Irrigation in the dry season can reduce the negative impacts on agricultural production because floods is the promotion of dry season irrigation. The various storage reservoirs established or planned in the country will provide valid options to reduce high discharges caused by excessive rainfall of short duration. This, however, requires an optimization of flood absorption through reservoir management which requires the reservoir to be appropriately drawn down for flood absorption.

\subsection{The application process of the “AQUAGEOHYCLIM" regional model}

The "AQUIGEOHYCLIM" regional approach is di- 
vided into three stages. Firstly, it examines climatic, hydrologic, geomorphic and aquifer characteristics of the Gash River. Secondly, it uses these characteristics to identify the physical environment of the Gash River. Thirdly, based on these characteristics, in addition to incorporating the community role, it recommends the methods for mitigation of catastrophic impacts. The importance of the "AQUIGEOHYCLIM" approach comes from its simplicity, its potential to deal with the available resources and its feasibility for use in any geographic setting. The application of this approach will come out after reviewing results (Fig. 5).

The application process of the model (Fig. 6) requires the flow of information through Gash River from source to delta. It includes, firstly, joint field investigations to various Gash River physical characteristics between Sudan and Eritrea in order to better understand its behavior; secondly, joint inte- grated information network between the two countries to detect torrential rains on catchment area of Gash River that will be consequent into torrential floods along the river; and thirdly, early warning system enhanced by local media to enable early standings against torrential floods. This information flow will be affected by control processes, including mechanisms designated by meteorological, hydrological and geological authorities to avoid or mitigate torrential floods impacts. In the third stage of the application process of the model, effectors are communities and early warning systems found along the river which will directly response to torrential floods. Finally, adaptive responses to torrential floods will mitigate its impacts as output that will feedback into future dealing with the river and into the creation of new adaptive mechanisms, in case the river appeared to have a new behavioral pattern.

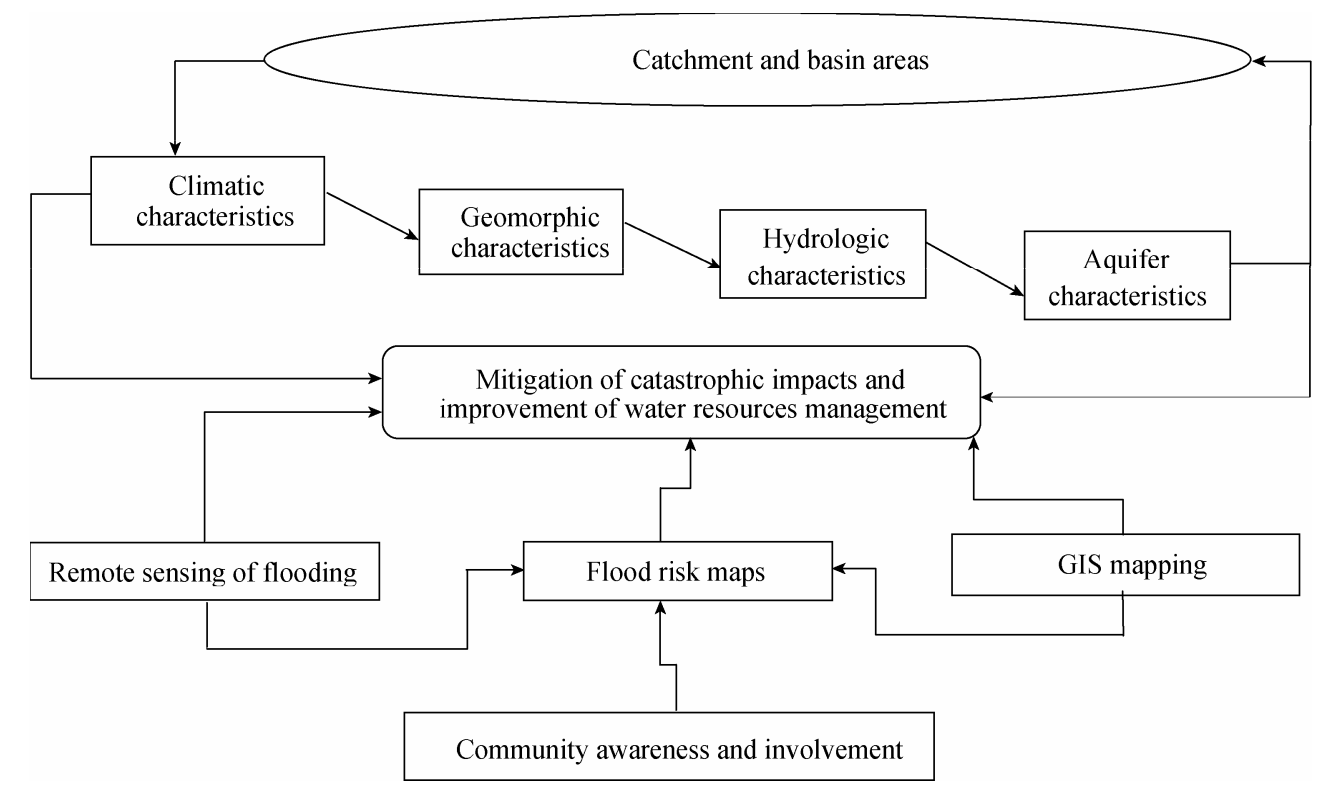

Fig. 5 Applied form of "AQUIGEOHYCLIM" approach for Gash River, Sudan

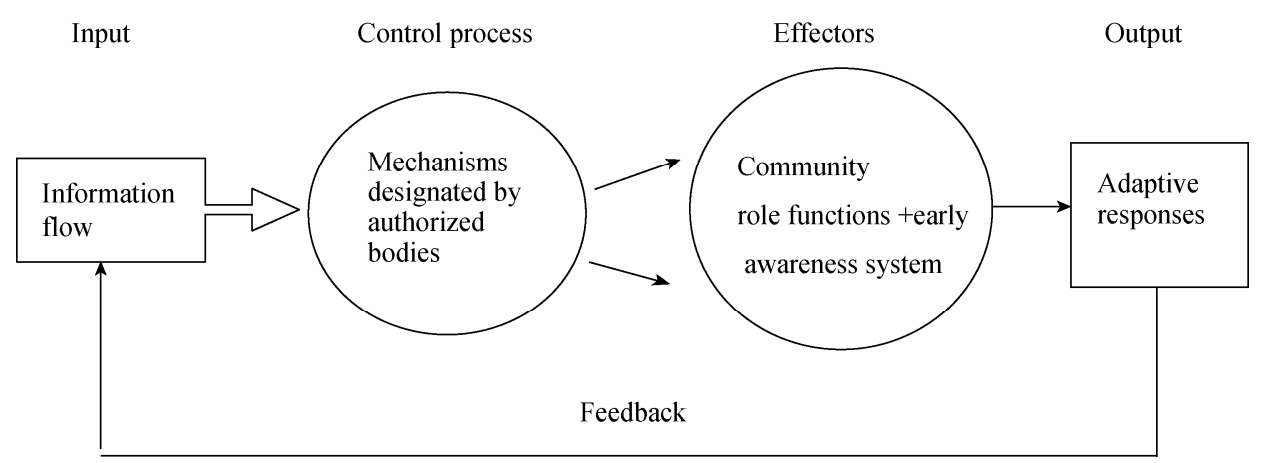

Fig. 6 Application process of the "AQUAGEOHYCLIM" regional model 


\section{Discussion}

Climatic, geomorphic, hydrologic and aquifer characteristics of the Gash River illustrate the variations in the hydrologic behavior of the Gash River. The reasons for such variations are related to the geological, environmental and geographical characteristics. The length of the Gash River is $450 \mathrm{~km}$ from the main source to the delta. Having the inherited characteristics across mountainous areas, the torrential river, the Gash River is fitting the youth stage of erosion theory. There are remarkable differences between source and delta of the Gash River which is slightly rolling and gently sloping. The type of rock enhances head erosion in catchment area and lateral erosion in the basin. The river course is rocky, narrow and perennial in the catchment area while it is wider and ephemeral in the basin area. Torrential rain in catchment area increases river flow velocity and causes quick torrential floods in the basin area, which initiates quick discharges and further is enhanced by the various geomorphic characteristics of the catchment area. Rapid change in velocity is related to the height of the plateau. The high elevation of the river source and underlying basement rocks had determined the slope angle, varying width, depth and length of the river. Torrential rain and continuous dropping in slope between source and delta of the river resulted in that the speed of the current was reduced and the river began to drop its load of sediment till it reached "Gash Die" at the end of the delta (Khogali, 2009). Huge quantities of silt measured were between $5 \mathrm{~kg} / \mathrm{m}^{3}$ and $10 \mathrm{~kg} / \mathrm{m}^{3}$, and therefore the river and its bed were continuously raised (Khogali, 2009). Sediment load is high in basin area due to high velocity, lateral erosion and transported sediment load from catchment area.

The stage-discharge rating curves display relatively large residual variance which is largely caused by rapid spasmodically changes of the stream bed of the Gash River (Eltom et al., 2010). Aquifer charging inflow and recharging outflow are tightly tied with rainwater infiltration, rock type and soil characteristics. Infiltration of flowing water as underground water is reflected on the water table in the study area. There are high values in hydraulic conductivity, transmissivity and discharge. The aquifer has high storage capacity, possibility to accept more water for storage, difference between annual groundwater inflow and outflow and the annual average recharge is low (ElKirail and Ibrahim, 2008). It is thought that in the past there was a deep depression in the north of the town and that at one time the Gash used to flow into the river Atbara (Barbour, 1961).

The Gash River is characterized by progressing deforestation (Kirkby et al., 2001). Deforestation causes an increase in the annual mean discharge. Further analyses present additional evidence that the change in vegetation cover altered the hydrological response and the pressure for changes in land cover continued to increase to make a possibility for expectation of further changes in the hydrological regime of a river (Marcos et al., 2003). In assessing the impacts of Himalayan deforestation on the Ganges-Brahmaputra Lowlands, it was found that forests would not have prevented or significantly reduced flooding in the case of an extreme weather event (Hamilton, 1987). However, more general or overview studies indicated that deforestation has the negative impacts on flood safety (Semi, 1989).

Hazards associated with torrential rains include flash floods, stream flooding and landslides. Heavy rain events can also be accompanied by strong winds and lightning. If a rain over an area for a long period of time, secondary damages can also occur because the ground becomes saturated with precipitation (Oblack, 2010). In many countries, the rivers prone to flooding are often carefully managed. Defenses, such as levees, bunds, reservoirs, weirs and dikes are used to prevent rivers from bursting their banks. Tide gates are used in conjunction with dikes and culverts. They can be placed at the mouth of streams or small rivers, where an estuary begins or where tributary streams, or drainage ditches connect to sloughs. In Europe and America there are coastal defenses, such as sea wall, beach nourishment and barrier island. Efforts of curbing the floods of the Gash River are based upon two strategies: one is to build earth embankments parallel with the main channel and another is building spurs.

\section{Conclusions and recommendations}

The general findings of this study are as follows:

(1) The Gash River has different geomorphic characteristics from the source to delta. 
(2) Rainfall amounts between catchment and basin areas are different.

(3) The Gash River has torrential discharge.

(4) The Gash River aquifer has high potentiality for water inflow, charge, recharge and storage.

(5) Above haracteristics have determined the physical environment of the Gash River.

This study could build a very strong case for mitigation catastrophic impact of torrential rivers. This could be done by incorporating the "AQUIGEOHYCLIM" regional approach, which could depend on environmental and geographical information.

\section{References}

Abdullatif O M. 1989. Channel-fill and sheet-flood facies sequences in the ephemeral terminal Gash River, Kassala, Sudan. Sedimentary Geology, 63(1-2): 171-184.

Barbour K M. 1961. The Republic of the Sudan: A Regional Geography. London: University of London.

Bashar K E, Gamal M A, Gadain H. 2005. Use of space technology in the management of Wadi water resources. Proceeding of the Third International Conference on Wadi Hydrology Sana'a, Yemen. Dec. 12-14, 2005. New York: UNESCO Publishing, 1-456.

ElKirail A B, Ibrahim A. 2008. Regional groundwater flow planning of Gash River basin, Sudan. Journal of Applied Science in Environmental Sanitation, 3(3): 157-167.

Eltom A M, Khalid A E, Zein E, et al. 2010. Groundwater budget for the upper and middle parts of the Gash River Basin, eastern Sudan. Arabian Journal of Geosciences, doi: 10.1007/s12517-010-0184-4.

Encarta. 2008. "Encarta-flood-control Flood Control". MSN Encarta. [2009-10-31]. http://www.webcitation.org/wiki.

Güntner A, Bronstert A. 2004. Representation of landscape variability and lateral redistribution processes for large-scale hydrological approaching in semi-arid areas. Journal of Hydrology, 297(1-4): $136-161$.

Hamilton L S. 1987. "What are the impacts of Himalayan deforestation on the Ganges-Brahmaputra Lowlands and Delta? Assumptions and facts". Mountain Research and Development, 7(3): 256-263.

Hughes D A. 1995. Monthly rainfall-runoff approaches applied to arid and semiarid catchments for water resource estimation purposes. Hydrological Sciences Journal, 40(6): 751-769.

Khogali M. 2009. The future of Kassala. Sudan Studies, 39: 42-50.

Kirkby J, O'Keefe P, Howorth C. 2001. Introduction: rethinking envi-
The application of the "AQUIGEOHYCLIM" regional approach in the Gash River can work to assess expected torrential floods, mitigating their catastrophic impacts and might help to decide appropriate management methods for its water resources. However, the "AQUIGEOHYCLIM" model can also be applied for other similar torrential rivers in similar places in Africa, Asia and Latin America. The international cooperation in river management is important because many rivers are shared between many countries at times when water conflicts are increasing, population is growing faster and climatic change is impinging on water resources.

ronment and development in Africa and Asia. Land Degradation \& Development, 12(3): 195-203.

Lerner D N, Issar A S, Simmers I. 1990. Groundwater Recharge: A Guide to Understanding and Estimation Natural Recharge. Hannover: Heise.

Marcos H C, Aure'lie B, Jeffrey A C. 2003. Effects of large-scale changes in land cover on the discharge of the Tocantins River, Southeastern Amazonia. Journal of Hydrology, 283(1-4): 206-217.

Martinez-Mena M, Albaladejo J, Castillo V M. 2001. Factors influencing surface runoff generation in a Mediterranean semi-arid environment: Chicamo watershed, SE Spain. Hydrological Processes, 12(5): 741-754.

Oblack R. 2010. Torrential Rain. [2009-11-9]. http://weather.about. $\mathrm{com} / \mathrm{od} / \mathrm{t} / \mathrm{g}$.

Pilgrim D H, Chapman T G, Doran D G. 1988. Problems of rainfall-runoff modelling in arid and semiarid regions. Hydrological Sciences Journal, 33(4): 379-400.

Semi N S. 1989. "The Hydrology of Disastrous Floods in Asia: An Overview". In: Starosolszky O, Melder O M. Hydrology of Disaster. London: World Meteorological Organization, 106-122.

Wheater H S, Butler A P, Stewart E J, et al. 1991. A multivariate spatial-temporal approach of rainfall in southwest Saudi Arabia. I. Spatial rainfall characteristics and approach formulation. Journal of Hydrology, 125(3-4): 175-199.

Wheater H S. 2008. Approaching hydrological processes in arid and semi-arid areas: an introduction to the workshop. In: Wheater $\mathrm{H}$, Sorooshian S, Sharma K D. Hydrological Approaching in Arid and Semi-Arid Areas. Cambridge: Cambridge University Press, 1-20.

Wikipedia. 2010. Flood mitigation. [2009-12-11]. http://en.wikipedia. org/wiki. 